\title{
The Effect of Video Conference Assisted Online Learning on Students' Mathematical Problem Solving Ability during the Covid-19 Pandemic
}

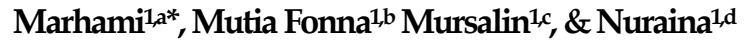 \\ ${ }^{1}$ Department of Mathematics Education, Universitas Malikussaleh, Aceh Utara, Indonesia \\ a marhami@unimal.ac.id; b mutia.fonna@unimal.ac.id c mursalin@unimal.ac.id; d nuraina@unimal.ac.id \\ *Corresponding Author : marhami@unimal.ac.id [ Phone : +6285277929008 ]
}

\begin{abstract}
This study aims to determine whether online learning assisted with video conferencing affects students' mathematical problem solving abilities during the Covid-19 pandemic. This research is a quasi experimental research type with a quantitative approach and a nonequivalent control group design. The population in this study were all students of mathematics education at the University of Malikussaleh semester III and the sample consisted of two classes, namely the experimental class and the control class. Data collection techniques are tests of mathematical problem solving abilities that have been tested and analyzed. The data analysis technique used is using the $t$ test with terms of normality and homogeneity. The result of the research obtained is that there is an effect of online learning assisted by video conferencing on students' mathematical problem solving abilities during the Covid-19 pandemic.
\end{abstract}

Keywords: Online learning; video conferencing; problem solving skills;

\section{Introduction}

The development of Information Technology has encouraged various innovations in the field of education. One of the steps to utilize network technology and information technology for the development of learning systems in higher education is the online lecture system (online). The spread of the corona virus is felt by the community both in the economic sector and in the field of education. One of the government policies in the world of education to break the chain of spreading Covid-19 is by implementing online or online learning. According to Sobri, et al (2020: 66) The online-based learning system is an implementation of Distance Education in Higher Education which aims to increase equitable access to quality learning. In the learning process, mathematics is a universal science that underlies the development of modern technology. Sari (2015: 713) suggests that mathematics as a compulsory subject is expected not only to equip students with the ability to use calculations or formulas in doing test questions but also to be able to involve their rational and analytical skills in solving everyday problems. It is hoped that various mathematical abilities can be achieved in learning mathematics from elementary school to higher education. The 2000 National Council of Teachers of Mathematics (NCTM) in a book entitled 'Principles and Standards for School Mathematics' states that the five mathematical abilities that students should have are (1) mathematical communication; (2) mathematical reasoning; (3) solving mathematical problems; (4) mathematical connection; (5) mathematical representation.

Problem-solving abilities are one of the abilities contained in the five NCTM standards that students and prospective teacher students should have. A problem usually contains a situation that encourages someone to solve it but does not know directly what to do to solve it (Suherman, 2003). Furthermore Hidayat and Sariningsih (2018: 111) suggest that problem solving contains four steps to solve it, namely understanding the problem, planning the problem, solving the problem according to plan and checking all the steps taken. One stage to the next in problem solving to support each other to produce solutions to the problems contained in the problem. Students play a role in understanding each step in problem solving so that the thinking process runs well. In the learning process, a mindset is needed that results in solutions to problems.

The learning process for prospective teacher students, which is usually face-to-face, in the past year has been more dominant using online learning in accordance with educational policies during the Covid-19 pandemic. This is in accordance with the Circular of the Minister of Education and Culture Number 3 of 
2020 dated 9 March 2020 concerning Prevention (COVID-19) in the Education Unit, then the Circular of the Minister of Health Number HK.02.01/MENKES/199/2020 dated 12 March 2020, more continued Circular of the Secretary General of the Ministry of Education and Culture Number 36603/A.A5/OT/2020 concerning the Prevention of Corona Virus Disease within the Ministry of Education and Culture (COVID-19) dated March 15, 2020 and WHO Health Protocol on March 6, 2020. Following up on this Circular and Health Protocol, the Chancellor of Malikussaleh University issued a Circular regarding the lecture process during the Covid-19 pandemic with Number: 1/UN45/HM.02/2020 concerning Prevention Measures for the Spread of Corona Virus Disease (COVID-19) at Malikussaleh University Environment. One of the academic protocols, namely lectures (face-to-face, structured assignments and independent assignments) is carried out online (online) using the available facilities. Various online learning systems (online) that are implemented within the scope of Malikussaleh University include the Unimal E-Learning application, Zoom, Google Classroom, Google Meet, Whats App etc. The success of the online learning system depends on several components, including students, lecturers, learning resources and information technology. Each of these components should be integrated in order to get qualified student graduates as well.

Thus, in simple terms, it can be said that online learning is learning using the help of the internet, by paying attention to various learning methods (learning process system design), seeing the evaluation of a series of learning activities using online learning, and also the presence of a feedback mechanism from the organizers. The implementation of online learning (Mustofa, et al: 2019: 154) provides benefits, including 1) a graphic increase in the quality of tertiary institutions and the quality of graduates, 2) the formation of a knowledge-sharing community that is not limited to one location, 3) an increase in an intense communication between lecturers and students, 4) unlimited learning resources, and 5) increased quality of lecturers due to easier access to information

In this study, online video conference-assisted learning was carried out using the Zoom Platform. Video conferencing is a service that provides facilities to bring together two or more parties using a broadband internet network. The concept of video conferencing is to use the conversion of sound converted by a microphone into a sound signal, and the image is converted by the camera into an image signal. The two signals are then compressed using a device called a codec. Then the compressed signal can be spread over the internet, in this case using IP, so that it can be sent and received according to the desired destination. Alfiani (2016: 85) states that learning media using video is very helpful in the learning process both formal and non-formal. According to Mustofa, et al (2019: 153-154), there are three things related to the development of online lectures, namely content, channels, and information technology. In this regard, the teaching and learning process is carried out through an internet connection and the availability of facilities for every student in its services. Apart from this, there are additional prerequisites, namely: the existence of an e-learning activity organizer, a positive main set of lecturers and students in the main function of the internet, a learning process system design that can be studied by all students, and evaluation process of a series of student learning processes and a feedback mechanism from the organizers.

Based on this Circular, the implementation of learning at the University of Malikussaleh is carried out online with various available facilities. This is an important part of the learning process, especially for prospective teacher students in mathematics education study programs, where one of the measured abilities is the ability to solve mathematical problems which can be seen directly when the student is solving problems with various levels of difficulty. however the implementation of lectures is currently not face-toface but online (online) so it is necessary to know how the effect of online learning itself for prospective teacher students on their mathematical problem-solving abilities, coupled with the various obstacles faced by students when implementing online lectures (online). According to Subaidi (2016: 64) difficulties in solving mathematical problems, one of which is shown by giving up behavior when having difficulty learning or solving problems. This behavior also appears when students get information about a material that the material is difficult, so students tend not to have the confidence to be able to learn it or even solve problems related to the problem. Students or student-teacher candidates tend to be able to read mathematics material directly from books but are unable to understand what they are reading. Plus the learning process is carried out not face to face. Based on the description above, the purpose of this research is to find out whether there is an effect of online learning assisted by video conferencing on student problem-solving abilities during the Covid-19 pandemic.

\section{Research Methods}

This study uses a quantitative research approach with an experimental method in the form of a quasiexperimental. The quasi-experimental method is a design that has a control group, but it cannot fully function to control external variables that affect the implementation of the experiment. Therefore, in grouping research subjects based on groups that have been formed before or groups that already exist. 
This research was conducted on the third semester of mathematics education students at the University of Malikussaleh in the 2020/2021 academic year. The population of this study were all third semester students of the Malikussaleh University Mathematics Education Study Program. Samples were taken by saturated sampling, namely class A1 students as the control class and class A2 as the experimental class. This research was conducted in the Number Theory subject in the division material. In class A1, online learning is conducted via video conferencing, while class A2 is learning online (without video conferencing). The design used in this study includes three stages, namely: (1) the research instrument development stage, (2) the research instrument trial stage, (3) the research implementation stage. Each stage is designed so that valid data is obtained according to the characteristics of the variables and research objectives. The research design used in this study was a non-equivalent control group design. In this design there are two groups selected by sampling saturated with the experimental design based on Creswell (2012), namely as follows:

Experiment Class Control Class

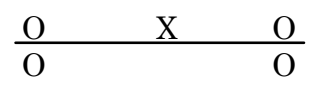

Information :

$\mathrm{O}$ : Pretest or posttest of students' mathematical solving abilities

$X$ : Online video conference assisted learning

The instrument used in this study was a set of tests of students 'mathematical problem-solving abilities which would be measured through the students' ability to solve questions that contained indicators of this ability. The mathematical problem-solving ability test consists of questions in the form of descriptions given after learning. In order to obtain good test questions, students' mathematical problem solving test questions are first tested and assessed for their validity, distinguishing power, difficulty level and reliability. The indicators of mathematical problem solving abilities used in this study are: After the data is obtained from the pretest and posttest results based on mathematical problem solving abilities, data processing is carried out. Data processing is carried out based on the problems in this study. Starting with the prerequisite test for data analysis such as the homogeneity and normality test before analyzing the hypothesis using the t-test. The normality test is intended to determine whether the data from each learning group is normally distributed or not. Testing the normality of researchers using the Shapiro-Wilk test. Operationally the hypothesis is formulated:

$\mathrm{H}_{0}$ : Data comes from populations that are normally distributed

$\mathrm{H}_{1}$ : Data comes from a population that is not normally distributed

The homogeneity test is intended to determine whether the two distributions, namely the experimental group and the control group, have the same variances or not. Researchers used the IBM SPSS 22 program, namely the levene test. Operationally the hypothesis is formulated:

$\mathrm{H}_{0}: \sigma_{1}^{2}=\sigma_{2}^{2}$ the variance of the experimental group data is the same as the control

$\mathrm{H}_{1}: \sigma_{1}^{2} \neq \sigma_{2}^{2}$ the variance of the experimental group data was different from the control

In the next stage, the hypothesis is tested after the data is declared to be normally distributed and homogeneous. The average difference test was carried out to determine the increase in students' mathematical problem solving ability in the experimental group better than the control group by using the $t$ test statistical test. If the data obtained is not normally distributed, the test is carried out with non-parametric tests (Mann Whitnry U Test). Operationally the hypothesis is formulated:

$\begin{array}{ll}\mathrm{H}_{0}: \mu_{1}=\mu_{2} & \text { There is no effect of online learning on students' mathematical problem solving abilities during the } \\ & \text { Covid-19 pandemic } \\ \mathrm{H}_{1}: \mu_{1} \neq \mu_{2} & \begin{array}{l}\text { There is an effect of online learning on students' mathematical problem solving abilities during the } \\ \text { Covid-19 pandemic }\end{array}\end{array}$

Testing criteria:

if the value is Sig ( $p$-value $)<\alpha(\alpha=0,05)$, then H0 is rejected

if the value is $\operatorname{Sig}(p$-value $) \geq \alpha(\alpha=0,05)$, then H0 is accepted

\section{Results And Discussions}

Before the implementation of learning, the two classes were first given a pretest to see whether there was a significant difference in the students' initial abilities in the experimental and control classes. After learning, post-test questions were given again to see if there was an effect of learning on problem solving abilities. To test these two data with the $t$ test, first the analysis prerequisite test was carried out, namely the normality and homogeneity test. The normality test of the pretest and posttest scores was calculated using the SaphiroWilk test assisted by the IBM SPSS 22 software.The test criteria with $a=0.05$ were as follows: 
if the Sig (p-value) $<\alpha(\alpha=0.05)$, then $\mathrm{H}_{0}$ is rejected

if the Sig (p-value) $\geq \alpha(\alpha=0.05)$, then $\mathrm{H}_{0}$ is accepted

Table 1. Data on the Results of the Saphiro-Wilk Normality Test

\begin{tabular}{ccccccc}
\hline \multirow{2}{*}{ Class } & \multicolumn{3}{c}{ Pretest Data } & \multicolumn{3}{c}{ Posttest Data } \\
\cline { 2 - 7 } & Stat. & Df & Sig. & Stat. & Df & Sig. \\
\hline Control & 0,939 & 24 & 0,151 & 0,45 & 24 & 0,079 \\
\hline Experiment & 0,931 & 24 & 0,104 & 0,79 & 24 & 0,045 \\
\hline
\end{tabular}

Based on the Table 1 above, it is found that the pretest data on students' problem-solving abilities in the experimental class and control class has a Sig. > a, then H0 is accepted, which means that both classes come from a normally distributed population. The next test is the homogeneity test to see whether the two classes have the same variances or not. In the homogeneity test using the Levene test the Sig value was obtained > a, namely 0.0650 .05 , then accept $\mathrm{H} 0$, which means that both classes come from a homogeneous population. After fulfilling the prerequisite test, the pretest data will be tested with the $t$ test. The test results obtained:

Table 2. Pretest Data t-test results

\begin{tabular}{ccc}
\hline $\mathrm{t}$ & $\mathrm{df}$ & Sig. \\
\hline$-0,594$ & 46 & 0,555 \\
\hline
\end{tabular}

From Table 2 it can be seen that Sig. > a, it can be concluded that the experimental class and the control class have the same mathematical problem solving ability before being given treatment. So that this will not affect the final score after learning. After the pretest, the two classes will be given different learning, namely the experimental class with online learning assisted by video conferencing, while the control class with online learning without video conferencing. Hypothesis testing begins with a normality test, the results of which can be seen in Table 1. Unlike the pretest, the control class in the post-test data has a Sig. < a, namely $0.045<0.05$, which means that the class is not normally distributed. So there is no need to do a homogeneity test but directly use the nonparametric test (Mann-Whitney U-Test). The results of the Mann-Whitney U test obtained the Sig. that is 0.039 then the Sig. < a which means reject H0. It can be concluded that there is a significant effect of online learning assisted by video conferencing on students' mathematical problem solving abilities during the Covid-19 pandemic.

In addition to the results of the analysis test which showed that online learning assisted by video conferencing had a significant effect on the mathematical problem solving abilities of students during the Covid-19 pandemic, this was also shown in the average post-test score of students' mathematical problem solving abilities in the class that applied online video learning. conference was 13.71, higher than students in classes that applied online learning without video conferencing, which was 12.46. These results illustrate that online learning with video conferencing has a positive effect in developing students' mathematical problemsolving abilities during the Covid-19 pandemic. This finding is in line with the research results of Yulianto (2020) and Mustakim (2020) that students' mathematical problem-solving abilities and the quality of online learning are further improved by using a video conference platform. Furthermore, these findings prove that with the help of video conferencing, distance learning is more interactive, thus providing opportunities for students to be more active and motivated in learning (Permatasari, 2018; Candarli \& Yuksel, 2012; Robert, 2009)

In online learning assisted by video conferencing, lecturers and students can interact directly like normal learning in class even though it is a long distance. This helps students to better understand and master the material being taught. In addition, students can also be directly guided in planning/formulating strategies to solve the problems given. Students are more directed to solve mathematical problems, so that students' critical attitude in learning grows and creates student responsibility in doing assignments independently. In the experimental class which was taught by online learning assisted by video conferencing, students were more active in asking questions and the lecturer could be more flexible in answering and guiding students to solve mathematical problems compared to the control class where students were taught online learning without the help of video conferences. In this group the material is taught indirectly in the sense that students learn without face-to-face distance and the discussions that take place are less interactive.

Mathematical problem solving abilities include indicators of understanding problems, planning problems, solving problems as planned and checking all steps taken. All of these things can be seen directly when the student is solving questions with various levels of difficulty. By using video conferencing assisted learning, the lecturer can pay attention to how the development of student abilities and students can also discuss, interact and ask questions directly and problem solving. This can be one of the causes of the development of students' mathematical problem solving abilities. 


\section{Conclusion}

Based on the results of research and discussion, it can be concluded that online learning assisted by video conferencing has an effect on the mathematical problem solving abilities of students during the Covid-19 pandemic. With the help of video conferencing, online learning feels more alive, interactive and active.

\section{References}

Alfiani, D. (2016). Pembelajaran Berbasis Video Untuk Anak Generasi Z. Prosiding Inovasi Pendidikan di Era Big Data dan Aspek Psikologinya. ISSN: 2548-5407. PascaSarjana Universitas Negeri Malang, hal 85-92

Candarli, D., \& Yuksel, H.G. (2012). Students' Perceptions Of Video-Conferencing In The Classrooms In Higher Education. Procedia - Social And Behavioral Sciences. 4(7): 357 - 361

Hidayat, W. \& Sariningsih, R. (2018). Kemampuan Pemecahan Masalah Matematis dan Adversty Quotient Siswa melalui Pembelajaran Open Ended. Jurnal Nasional Pendidikan Matematika, 2(1): 109-118

Kemdibud. (2020). Surat Edaran Menteri Pendidikan dan Kebudayaan tentang Pencegahan (COVID-19) Pada Satuan Pendidikan. [Online]. Tersedia: https://www.kemdikbud.go.id [25 Juli 2020]

Kemenkes. (2020) Surat Edaran Menteri Kesehatan tentang Komunikasi Penanganan Corona Virus Disease 2019 (COVID-19). [Online]. Tersedia: https:/ / www.kemkes.go.id [25 Juli 2020]

Mustakim. 2020. Efektivitas Pembelajaran Daring Menggunakan Media Online Selama Pandemi COVID-19 Pada Mata Pelajaran Matematika. Journal of Islamic Education. 2(1), 1-12

NCTM (2000). Principles and Standards for School Mathematics. Reston, VA: NCTM

Permatasari, Y.B. (2018). Male And Female Students' Perceptions Toward The Implementation of Video Conference As A Distance Learning Media That Enhances Teachers' Productivities. Journal of Applied Linguistics and Literacy. 2(2): 101-112.

Robert, R. (2009). Male and Female Students' Perceptions Toward The Implementation Of Video Conference As A Distance Learning Media That Enhances Teachers' Productivities. Journal of Distance Learning. 13(1): 91-107.

Sari, N. (2015). Literasi Matematika: Apa, Mengapa dan Bagaimana?. Seminar Nasional Matematika dan Pendidikan Matematika UNY. ISBN. 978-602-73403-0-5, hal: 713-720

Setjen Kemdikbud (2020). Surat Edaran Sekretaris Jenderal Kementerian Pendidikan dan Kebudayaan tentang Pencegahan Corona Virus Disease di lingkungan Kementerian Pendidikan dan Kebudayaan (COVID-19). [Online]. Tersedia: https://setjen.kemdikbud.go.id [25 Juli 2010]

Sobri, M. Nursaptini. \& Novitasari, S. (2020). Mewujudkan Kemandirian Belajar melalui Pembelajaran Berbasi Daring di Perguruan Tinggi pada Era Industri 4.0. Jurnal Pendidikan Glasser, 4(1): 64-71.

Suherman, E. (2003). Evaluasi Pembelajaran Matematika. Bandung: JICA UPI.

Unimal (2020). Surat Edaran tentang Tindakan Pencegahan Penyebaran Corona Virus Disease. (COVID-19) di Lingkungan Universitas Malikussaleh. [Online]. Tersedia: http://www.unimal.ac.id [26 Juli 2020]

Yulianto (2020). Pengaruh Pembelajaran Daring Pengguna Platform Digital Terhadap Pemecahan Masalah Matematis danSikap Kritis Siswa Di MA Daar El Qolam. Pasundan Journal of Research in Mathematics Learning and Education. 5 (1): 107-128. 